The technique developed by Marquardt, of capping the stump with an auto- or homograft of bone and cartilage and following this up with a special postoperative training with increasing pressure on the end of the stump, prevents overgrowth and penetration and normalizes regular growth. Additional distraction and later angulation osteotomy allows shoulder-free prosthesis fitting with direct transfer of all shoulder motions to the prosthesis.

Key words: Amputation, stump overgrowth - Graft, bone, cartilage - Stump, lengthering, natural, artificial - Stump: Capping.

Zusammenfassung. Wiederholte Nachamputationen wachsender Oberarmstümpfe wegen drohender Durchspießung verursachen eine zunehmende Stumpfverkürzung.

Die von Marquardt entwickelte Stumpfkappenplastik mit einem auto- oder homologen Knochen-Knorpel-Transplantat und dosiertem postoperativem Belastungstraining vermeidet erneute Durchspießungen, führt zu guter Stumpfendbelastbarkeit und zu normaler Längenzunahme. Zusätzliche Distraktion ermöglicht die Winkelosteotomie eines ausreichend langen Humerusstumpfes, danach die Versorgung mit einer schulterfreien Prothese mit erheblich größerem Aktionsradius im Vergleich zu herkömmlichen Prothesen.

Schliisselwörter: Durchspießung, drohende - Stumpfkappenplastik - Knochen-Knorpel-Transplantat - Stumpflängenzuwachs.

\title{
88. Zur Differentialdiagnose und Behandlung der posttraumatischen Periarthropathia humeroscapularis
}

\author{
D. Sarfert
}

Unfallchirurgische Universitätsklinik Mainz, Langenbeckstr. 1, D-6500 Mainz

\section{Differential Diagnosis and Treatment of Posttraumatic Periarthropathia humeros- capularis}

Summary. Periarthropathia humeroscapularis is the neutral general clinical term that has been coined for painful frozen shoulder without a clear etiology. From the clinical and therapeutic viewpoint and that of its special pathogenesis, periarthropathia humeroscapularis can be categorized into four forms: acute to chronic, frozen shoulder, and the syndromes of the biceps-longus tendon and supraspinatus tendon. Treatment should abolish the acute irritation and prevent proliferation. The application of heat is absolutely contraindicated in the acute stage. Ice packs placed at the exact location of the irritation would be the treatment of choice, in addition to analgesics, antiphlogistics and sedatives in the acute stage.

Key words: Periarthropathia humeroscapularis - Shoulder, frozen - Cryotherapy.

Zusammenfassung. Für schmerzhafte Schultersteifen unklarer Genese wurde der neutrale klinische Oberbegriff der Periarthropathia humeroscapularis eingeführt, der wegen der speziellen Pathogenese unter klinisch-therapeutischen Gesichtspunkten in 4 Erscheinungsformen aufzuschlüsseln ist: die akute bis chronische, die ankylosierende und die Syndrome der Bicepslongus- und SupraspinatusSehnen. Die Therapie soll den akuten Reizzustand aufheben und proliferative Veränderungen verhindern. Im akuten Stadium sind als physikalische Behandlungen Wärmeanwendungen absolut kontraindiziert. Gezielte Kälteanwendungen mit Eispackungen sind hier die Methode der Wahl neben Analgetica, Antiphlogistica und Sedative.

Schlïsselwörter: Periarthropathia humeroscapularis - Kryotherapie. 